\title{
The Social and Environmental Effects of Foreign Investment in Kosovo
}

\section{Halim Bajraktari}

Prof. Assoc. Dr, Law Faculty, KosovoUniversity "Ukshin Hoti" of Prizren,

Rifat Hoxha

Prof. Ass. Dr., Faculty of Economy, University "Ukshin Hoti" of Prizren, Kosovo

Agon Kokaj

Prof. Ass. Dr. Msc.Dip.Ing, Faculty of Computer Science, University "Ukshin Hoti" of Prizren, Kosovo

\section{Abstract}

The effects of different foreign companies that are expected to invest in Kosovo is a significant aspect of its effect in the environment. Pollution is an important factor that has become a major problem today. The geo-physical status of the country, situated in the central Balkans region, happens to be a corridor of economic change and prosperity. That prosperous positive upcoming change may be halted due to the continuous disruption of toxic and poisonous fumes being released into the atmosphere. Institutions are expected to undergo a real-time monitoring technique that will be able to allow certain factories to set up their headquarters and allow for production in law abiding rules and in full relation to the health environmental issue.

Keywords: Economy, prosperity, environment, health, toxic.

\section{Introduction}

The country's economy is highly dependent on healthy foreign and domestic investment. Nations that are net yet highly developed, like countries in the west, are facing a very different situation. It happens to be that they have not met the standard requirements for investment. It is required that those standards are up to the dated requirements and that it would include the health issue as well as the well-being of clean air and the minimum requirement of pollutants being released into the atmosphere.

\section{The major problem}

Even though there happens to be an acceptable lawful purpose as to what degree level the air can be or is allowed to have a specific coefficient of pollutants into the atmosphere, that would underline the fact that this law is not respected by many investors along with the companies. Such companies have managed to employ many people and have created new jobs, however they have not respected the law that prohibits the high levels of pollution into the atmosphere.

It would be reasonable to dignify the fact that on the long term investors are willing to invest in places and countries where they can get a better deal rather than having to focus on the environmental health issue problem effecting the atmosphere. If one was to analyse the 
situation on the long term, then we would understand that such a case would have serious replication's on the country's environmental and polluted cities, this would also take into account that as well as the motion were serious investors would be interested to come and invest in places where there is a law abiding institution.

According to the (AKMM, 2018), in Kosovo, the levels of $\mathrm{NO}_{2}$ have indicated that they have surpassed the continental acceptable values of VML $40 \mu \mathrm{g} / \mathrm{m} 3$ ) in two distinct cities HaniElezi, Gjilan and Prizren. It's pretty much the same in neighboring countries like Albania(SH.com,2020). It is believed that $60 \%$ of the population live in areas where dust and mini-pollutants have overpassed the acceptable levels of clean air that would be in accordance to OBSH $35 \mu \mathrm{g} / \mathrm{m} 3$. The world health organization has emphasized that lowering the level of pollution into the atmosphere from 70 to $20 \mathrm{ug} \cdot \mathrm{m}^{-3}$ will lower the death rate by $15 \%$ caused from polluted air.

This brings into the account the fact that serious investors will not invest into countries like Kosovo where it will cause an increase in the level of pollution into the atmosphere and at the same time lowering the company's image in the business world. Therefore, it must be taken into account that foreign investment is in proportion to the health environmental problem and the pollution in the atmosphere.

\section{The Social effects to the problem}

The society is highly effect by the rate of investors as to where and how they will decide on their investment strategy. The Energy we use is directly related to the environmental effect. This will bring into account that the greenhouse gases that have also had an effect as to how much we can tolerate the factories that allow pollutants into the atmosphere. The oxides released into the atmosphere have shown a great deal of impact as to how much we can allow more investors to invest in some highly populated areas. The location to be decided for certain power plants is another important factor that has to be taken into account. This is because toxic fumes and waist can harm the environment.

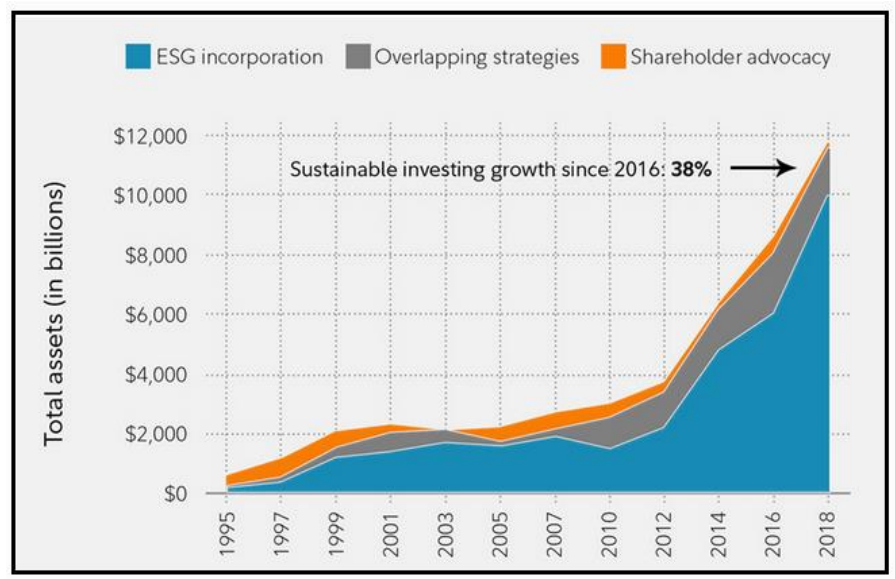

Figure 1: Sustainable Investments (www.forbes.com, 2019)

According to figure 1, it can be seen clearly that towards the end of the year 2016 an increase in the investment growth has been raised and it has given rise to a continuous growth. We can 
base this data and take into account the fact that this investment has to be carried out and that it brings into work more jobs.

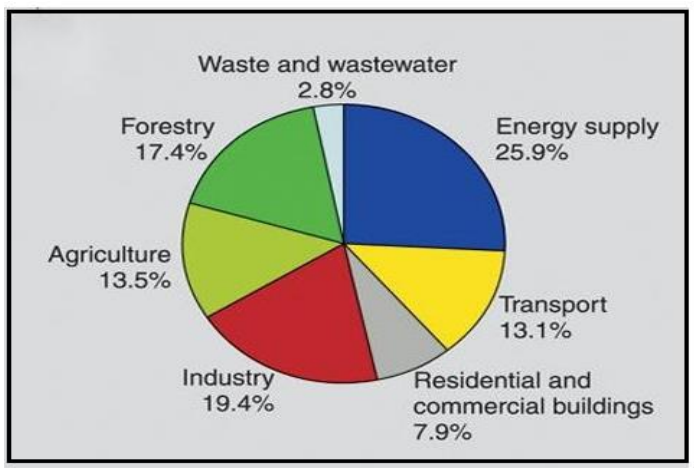

Figure 2: The Greenhouse emission (O'Connor, 2009)

Figure 2 shows the total greenhouse emission for the year 2004. It can be clearly understood that the highest level of pollutants and toxic is mainly from the energy supplier sector and the industry. This is a very important because these two sectors are sectors for an increment in job requirements and we do expect that these figures to continue to grow more. It must be taken into account that in regard to these two sectors both are highly essential and that they must meet the so called environmental friendly demand that will not contribute to increasing the levels of pollution and its pollutants.

\section{Significant Analysis}

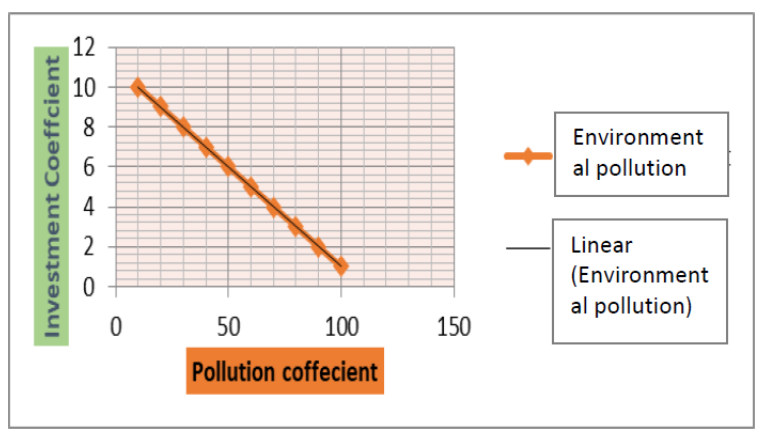

Figure 3: The Investment Report (Yeoh, 2019)

Figure 3 shows the potential investment ability in relation to the levels of pollution. It can be understood here that as the level of pollution continues to increase the chances of investment decrease. This indirect rationality was further analysed and we understood that it would require an online twenty-four 7 measurements, on the levels of pollution in the atmosphere in order for us to understand and take into account the fact that we require a certain level of efficiency, allowing us to be maintained within the acceptable range. In addition to that we will still be allowed to have continuous acceptable investment strategies. 


\section{Conclusions}

We believe that this paper makes an important contribution to the economic development of the country because it incorporates two positive elements. The first is that it emphasizes the importance of ambient, the clean air for a developed country and a healthy life, and the second enables companies to calculate their exact level of pollution at which they are able to function using a very low cost model, which is easy to use and implement and provides us with very precise results.

\section{Bibliography}

[1] AKMM. (2018). Raport vjetor per cilesine e ajrit ne Kosove. Prishtine: Ministria e Mjedisit dhe Planifikimit Hapësinor.

[2] O'Connor, P. (2009, December 21). World Socialist Web Site. Climate change, emissions trading schemes and the profit system, p. 1.

[3] SH.Com, R. (2020, March 19). Shqiptarja.com. Raporti për cilësinë e ajrit, sa njerëz vdesin në Shqipëri nga ndotja, p. 1.

[4] Yeoh, N. (2019, October 29). Forbes. Sustainable Investing? Here's What Millennials Need To Know In The U.S., p. 1.

[5] https://www.forbes.com/sites/neilyeoh/2019/10/26/sustainable-investing-hereswhat-millennials-need-to-know-in-the-u-s/\#73f6814b1e8a

[6] https://www.wsws.org/en/articles/2009/12/etpo-d21.html

[7] https://www.who.int/

[8] http://niph-rks.org/

[9] https://indep.info/wp-content/uploads/2019/08/INDEP_Qershor-2019_Cilesia-eajrit-ne-Kosove.pdf 